Influencia del tipo de vegetación y la temporada sobre el ensamblaje de roedores en un mosaico de bosque templado mexicano

\title{
Influence of vegetation type and season on rodent assemblage in a Mexican temperate forest mosaic
}

\author{
Rafael Flores-Peredo ${ }^{1 *}$ y Guillermo Vázquez-Domínguez ${ }^{2}$
}

\begin{abstract}
${ }^{1}$ Laboratorio de Ecología, Instituto de Investigaciones Forestales, Universidad Veracruzana. Parque Ecológico El Haya, Antigua Carretera Xalapa-Coatepec s/n, Xalapa, 91070. Veracruz, México. E-mail: peredofr@gmail.com (RFP).

${ }^{2}$ Laboratorio de Ecología Funcional, Instituto de Investigaciones en Ecosistemas y Sustentabilidad, Universidad Nacional Autónoma de México, Antigua Carretera a Pátzcuaro 8701, Morelia 58190. Michoacán, México. E-mail: vazquezdg@gmail.com (GVD).

* Corresponding author
\end{abstract}

Knowing the factors that influence abundance, distribution and species richness is key to establishing local conservation strategies. We evaluated the influence of vegetation type (pine forest, oak-alder-forest and grassland) and season (dry, wet), on the rodent assemblage (richness and abundance in space and time) in a mosaic of temperate forest in Mexico. The completeness of the inventory was evaluated by nonparametric estimators ACE and Jackknife. We used a GLM to evaluate the effect of vegetation type, season and interaction (vegetation type*season) on the richness and abundance of rodents. The effects of factors and their interaction on the abundance of each species were evaluated with twoway ANOVA with rank transformations. To analyze changes in the rodent assembly structure, we used rank-curves abundances and ANCOVA to assess differences in species relative abundance (dominance). We found that rodents were more abundant in the pine forest and during the dry season, but the interaction between oak-alder forest and the dry season also favored abundance. At the species level, Peromyscus melanotis was abundant in the pine forest and Reithrodontomys fulvescens in the oak-alder-forest. Between seasons, only the abundance of $P$. maniculatus and $P$. melanotis was higher in the dry season than the wet season. The results show that in a temperate forest mosaics with trees are of crucial importance for rodent conservation during the dry season. However connectivity among temperate plant communities (pine forest, oak-alder forest and grassland) must be a strategy to consider in the study of rodents assemblage and their dynamics in temperate forests.

Key words: abundance; dominance; Mus musculus; rainfall; species richness.

Conocer los factores que influyen en la abundancia, distribución y riqueza de especies es clave para el establecimiento de estrategias locales de conservación. Evaluamos la influencia del tipo de vegetación (pinar, encinal-ilital, pastizal) y la temporada (seca, lluviosa), sobre el ensamblaje de roedores (riqueza y abundancia en espacio y tiempo) en un mosaico de bosque templado en México. Usamos los estimadores no paramétricos ACE and Jackknife para evaluar la completitud del inventario de especies. Utilizamos un modelo lineal generalizado para evaluar el efecto del tipo de vegetación, la temporada y la interacción (tipo de vegetación*temporada) sobre la riqueza y abundancia de roedores. El efecto de los factores y su interacción sobre la abundancia de cada especie se evaluó con un ANOVA de dos vías con transformaciones a rangos. Para analizar cambios en la estructura del ensamblaje de roedores utilizamos curvas de rango-abundancia y usamos un ANCOVA para probar diferencias en la abundancia relativa de especies (dominancia). Encontramos que los roedores fueron más abundantes en el bosque de pino y durante la temporada seca, pero la interacción entre el encinalilital y la temporada seca también favorecieron la abundancia. A nivel de especie, Peromyscus melanotis fue abundante en el bosque de pino y Reithrodontomys fulvescens en el encinal-ilital. La abundancia de P. maniculatus y P. melanotis fue mayor en la temporada seca que en la de lluvias. Los resultados muestran que en un bosque templado los mosaicos con árboles son de vital importancia para la conservación de roedores durante la temporada seca. No obstante, la conectividad entre comunidades vegetales templadas (bosque de pino, encinal-ilital y zacatal) debe ser una estrategia a considerar en el estudio del ensamblaje de roedores y su dinámica en bosques templados. 


\section{Introduction}

Identification of the factors that influence patterns of distribution, abundance and richness of species are of central importance to develop conservation strategies of fauna and their habitat (Ofori et al. 2015; Manning and Edge 2008). The species assemblage is a useful concept in ecology, used to describe the arrangement of species and their interactions in space and time (Gee and Giller 1987; Jorgensen 2004). The structure of species assemblages is determined in part by environmental factors such as vegetation type and seasonal changes. Viewed as a habitat, a single vegetation type (e.g. pine forest) or a combination of these habitats (pine forest and grassland) can supply or complement the necessary resources (food, water, refuge, etc.) for assemblages of certain species, but the resource availability also may influence their habitat preference and affect the assemblage structure (LoGiudice and Ostfeld 2002). Moreover, seasonal variation such as the change from dry to wet seasons, also determines plant phenology. Changes in precipitation regimes and temperature fluctuations regulate the production, availability and quality of food (fruits, flowers, seeds, seedlings), which in turn influence the dominance of certain species (Pardini et al. 2005).

Among mammals, rodents are the most diverse group with numerous habitat associations, and comprise over $40 \%$ of all mammalian fauna globally (Wilson and Reeder 2005). They have complex effects on the structure, composition and functional diversity of their environment through various ecological interactions as pollination (Johnson et al. 2011), removal, depredation and dispersal of fruits and seeds (Sánchez-Cordero and Martínez-Gallardo 1998; Flores-Peredo et al. 2011), and dispersal of fungal spores (Castillo-Guevara et al. 2012). Small changes in the habitat can affect abundance, diversity and composition of some rodent species (Malcom and Ray 2000). As such, changes in the structure of small rodent communities can be used as indicators of habitat quality or environmental disturbance (Avenant 2011). Hence, to understand how environmental factors such as vegetation type and seasonal variation affect the ecology and population dynamics of rodent species, it is essential to design and implement local strategies to conserve species and manage their habitat (Vázquez et al. 2000). However, despite their ecological importance, research on small rodents carried out in Mexico has focused on single species or on basic inventories of species (Sánchez et al. 2003; Morales-García 2007; Hernández-Flores and Rojas-Martínez 2010; Cervantes and Ballesteros-Barrera 2012; González-Christen et al. 2012), with less attention on the effect of vegetation type and seasonality on the array of species or their habitat preferences.

Temperate forests in Mexico are comprised of different vegetation types, with pine forest and oak-alder-forest, often with grassland, being the most representative (González-Medrano 2004). These forests have marked dry and wet seasons between February-June and July-October, respectively (Rzedowski 2006) although through time these seasons may fluctuate due to factors such as climate change (Gómez-Mendoza and Arriaga-Cabrera 2007). The surface area of the temperate forest in Mexico has declined $27 \%$ (47 million hectares approximately) in the last 30 years because of anthropogenic disturbances (Sánchez-Colón et al. 2009; Siry et al. 2015). The surface area of temperate forests particularly in the state of Veracruz is 83,679 hectares and is inhabited by a total of 41 species of wild rodents (Ceballos and Oliva 2005). However, Veracruz ranks fifth nationally in terms of loss of forest area, mainly because of an expansion of agricultural areas, forest fires, illegal logging, and road expansion (Challenger 1998; CONAFOR 2010). Thus, knowledge of the spatial and temporal dynamics of species is important for anticipating the potential consequences of fragmentation and habitat loss on population dynamics of rodents (Lindenmayer and Fisher 2006). The objective of this research was to evaluate the influence of vegetation type, seasons and the interaction of both factors on rodent assemblages in the temperate forest mosaic in central Veracruz, Mexico. 


\section{Material and methods}

Study area. Our study was carried out in the San Juan del Monte Nature Reserve $\left(19^{\circ} 39^{\prime} 00^{\prime \prime}, 19^{\circ}\right.$ $\left.35^{\prime} 00^{\prime \prime} \mathrm{N},-97^{\circ} 05^{\prime} 00^{\prime \prime},-97^{\circ} 07^{\prime} 30^{\prime \prime} \mathrm{W}\right)$, in the Las Vigas de Ramírez municipality, Veracruz, Mexico. The altitude of the nature reserve varies from 2,327 to 3,100 masl and the area covers 609 hectares (Flores-Peredo et al.2011). The three main vegetation types included are: pine forest, dominated by species such as Pinus patula, P. pseudostrobus, P. montezumae and P. teocote, with heights between 15 and 25 m, oak-alder forest with predominance of Quercus crassifolia and Alnus jorullensis, with heights between 6 and $12 \mathrm{~m}$, and grasslands including predominantly native grasses such as Brachypodium mexicanum and Muhlenbergia macroura, up to $1 \mathrm{~m}$ in height, and to a lesser extent shrubs such as Baccharis conferta (Rzedowsky 2006).

Seasonal variation. We characterized the seasonal variation in the study area by constructing an ombrothermic (rainfall and temperature) diagram (Figure 1). We used the average monthly temperature and rainfall recorded during 2005 - 2007 by the weather station for the Las Vigas de Ramírez municipality, Veracruz, Mexico. The ombrothermic diagram showed that the dry season began in January and ended in May, with an average monthly temperature of $12.30{ }^{\circ} \mathrm{C}$, a rainfall of $235.77 \mathrm{~mm}$ ( $19.5 \%$ of annual total), and an average monthly rainfall of $39.29 \mathrm{~mm}$. January was the coldest month, and a slight increase in precipitation was observed during February. The wet season began in June and ended in October. The average temperature during this season was $11.84{ }^{\circ} \mathrm{C}$, with a rainfall of $973.87 \mathrm{~mm}(80.5 \%$ of annual total); with an average monthly rainfall of $162.31 \mathrm{~mm}$. April was the hottest and driest month of the year.

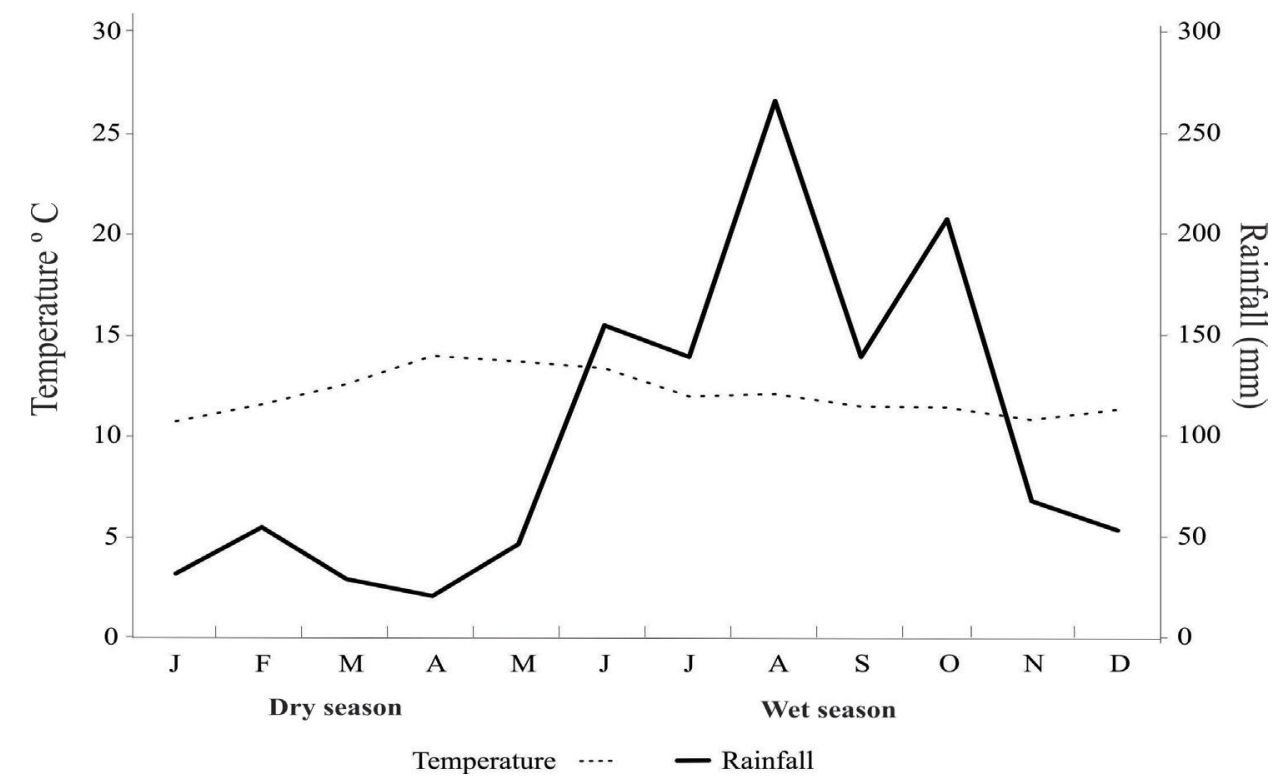

Figure 1. Ombrothermic diagram of the study area (2005 - 2007). Data are averages for the three years recorded and taken from the weather station (177 - 00030211) located in the municipality of Las Vigas de Ramírez, Veracruz, Mexico.

Rodent sampling design. According to the classification by Rzedowski (2006), we selected three vegetation types: pine forest, oak-alder forest, and grassland. A replica for each vegetation type was established and these were 3 - $4 \mathrm{~km}$ (mean $3.3 \mathrm{~km}$ ) separated from the other members of the pair. A grid was placed on each of these 6 replicated vegetation patches. These grids were 130 $\mathrm{m}$ by $130 \mathrm{~m}$ in size (1.7 ha), and had lines $5 \mathrm{~m}$ apart. Each grid was trapped twice per month. For each trapping period, two transects were randomly chosen for trap lines. One of these was 130 $\mathrm{m}$ long ( $5 \mathrm{~m}$ wide) and the other $120 \mathrm{~m}$ ( $5 \mathrm{~m}$ wide). Both transects were trapped for two nights in sequence. There were therefore 144 trapping periods ( 288 trapping nights) in total ( 6 grids $\times 2 \times$ 12 months). One week separated the two within-month trapping periods, and 9 days separated 
the between-month trapping. For each trapping period, a pair of two transects was set with 25 traps placed at $10 \mathrm{~m}$ intervals, and trapped for two consecutive nights for a total of 50 trap-nights per trapping period or 100 per month. Each grid experienced 1,200 trap-nights for the year (100 per grid per month $\times 12)$. All six grids totaled 7,200 trap-nights $(1,200 \times 6)$.

Rodent identifications. The identification of rodent species is very difficult in the field. Because of this, we euthanized by asphyxia an adult male and female of each rodent species (Robert 2016). Identification to species of euthanized individuals was based on cranial morphology according to Wilson and Reeder (2005). After identifying the euthanized individuals, we created our own photographic field guide, and in some cases we used voucher specimens. At the end of fieldwork, all euthanized specimens were deposited in the Universidad Veracruzana mammal collection. To record recaptures, all individuals captured were ventrally marked with indelible ink, and then they were released at the capture sites.

Rodent sampling efficiency. To assess the rodent inventory efficiency, we determined the saturation of the rodent assemblages (asymptote) in each vegetation type and season by computing species accumulation curves. We computed non-parametric species richness estimators for abundancebased data (ACE; Abundance-based Coverage Estimator) and for incidence-based data (using a jackknife procedure) using 1000 randomizations (Magurran 2004). We used the average of ACE and Jackknife estimators to estimate the percentage saturation of rodent assemblages for each vegetation type and season. According to Moreno and Halffter (2000), we considered a value of $90 \%$ completeness for the asymptote. All estimates were performed using the free license software EstimateS 9.1.0 (Colwell 2013).

Analyses of rodent assemblages. After checking for the assumptions in parametric analyses, we used a generalized linear model (GLM) with a Poisson distribution to test the effect of vegetation type and season and the interaction of both factors on species richness and abundance of rodents. The effect of vegetation type, season and its interaction on the abundance of each species was evaluated through two-way ANOVA test with rank transformation. For significant differences a multiple comparison Tukey test was used. To analyze seasonal and vegetation type changes in rodent community structure (dominance/evenness) we constructed rank-abundance curves (Magurran 2004). Then, to test differences in dominance/evenness of rodent species, we used an analysis of covariance (ANCOVA) to compare the slope of the rank-abundance curves according to vegetation type and seasonal period (Zar 2010). Because rank-abundance plots are not linear and do not follow a normal distribution, abundance of species was transformed to Log10 (Magurran 2004). Then, according to Log10 scale, we define dominant species as those taxa with values $\geq 1$ (10 individuals; Gotelli and Colwell 2011).

\section{Results}

Rodent inventory completeness. Of the nine rodent species collected, the most abundant were Peromyscus melanotis (31\%) and P. maniculatus (22\%; Table 1). Total species accumulation curves reach the asymptote after 33 sampling nights, but varied among vegetation types: 32 nights for the pine forest, 31 for mixed forest, and 20 for subalpine grassland (Figure 2a). According to the average for the non-parametric estimators, the level of inventory completeness was satisfactory (i. e., exceeded $90 \%$ ) only for the pine forest and grassland in the dry season and for pine forest and oak-alder in the wet season only (Table 1). We did not record recaptures of individually marked individuals.

Patch and seasonal changes in rodent assemblages. The pine forest had the highest richness of rodent species ( 8 species), followed by oak-alder forest ( 7 species) and grassland (5 species; Table 1 , Figure 2b). However, the GLM model indicated that interaction between factors (vegetation type* season) did not affect rodent richness $\left(F_{2,6}=0.21, P=0.8976\right)$, nor did individual factors, vegetation type $\left(F_{2,6}=4.27, P=0.1180\right)$ or season $\left(F_{1,6}=0.03, P=0.8617\right)$. In contrast, rodent abundance was affected by the interaction between vegetation type and season $\left(F_{2,6}=4.28, P=\right.$ 
Table 1. Diversity of rodents ( $n$, mean $\pm S D$ ) captured in the three vegetation types and during the two seasons in a temperate forest in central Veracruz State, Mexico. Numbers of individuals trapped (n), Relative abundance (RA = percentage of captures represented by each species), ACE: Abundance-based Coverage Estimator, Jackknife: is found by systematically leaving out each observation from a dataset and calculating the estimate and then finding the average of these calculations, considering the number of species that occur in a single sample, the number of species and the number of samples. Average estimators: is the average obtained by the sum of the two estimators (ACE and Jackknife) divided between two. The \% of completeness was calculated as follows: Richness*100/Average estimators.

\begin{tabular}{|c|c|c|c|c|c|c|c|c|c|}
\hline \multirow[b]{2}{*}{ Species } & \multirow[b]{2}{*}{$n$} & \multirow[b]{2}{*}{ RA\% } & \multicolumn{3}{|c|}{ Dry season } & \multicolumn{4}{|c|}{ Wet season } \\
\hline & & & Pine forest & Oak-alder & Grassland & Pine forest & & ak-alder & Grassland \\
\hline \multicolumn{10}{|l|}{ Cricetidae } \\
\hline Peromyscus melanotis & 77 & 31 & $2211.0 \pm 0$ & $157.5 \pm 0.5$ & $63.0 \pm 1.0$ & $2110.5 \pm 2.5$ & 11 & $5.5 \pm 0.5$ & $21.0 \pm 1.0$ \\
\hline Peromyscus maniculatus & 54 & 22 & $199.5 \pm 0.5$ & $6 \quad 3.0 \pm 0$ & $199.5 \pm 1.5$ & $21.0 \pm 1.0$ & 4 & $2.0 \pm 0$ & $42.0 \pm 1.0$ \\
\hline Microtus mexicanus & 3 & 1 & $0 \quad 0 \pm 0$ & $0 \pm 0$ & $0 \pm 0$ & $31.5 \pm 1.5$ & 0 & $0 \pm 0$ & $0 \quad 0 \pm 0$ \\
\hline Reithrodontomys mexicanus & 41 & 17 & $63.0 \pm 1.0$ & $42.0 \pm 2.0$ & $168.0 \pm 4.0$ & $0 \quad 0 \pm 0$ & 4 & $2.0 \pm 0$ & $115.5 \pm 0.5$ \\
\hline Reithrodntomys fulvescens & 32 & 13 & $31.5 \pm 0.5$ & $73.5 \pm 0.5$ & $31.5 \pm 0.5$ & $6 \quad 3.0 \pm 0$ & 10 & $5.0 \pm 1.0$ & $31.5 \pm 0.5$ \\
\hline Reithrodontomys megalotis & 15 & 6 & $11.0 \pm 0$ & $10.5 \pm 0.5$ & $6 \quad 3.0 \pm 0$ & $21.0 \pm 1.0$ & 3 & $1.5 \pm 0.5$ & $10.5 \pm 0.5$ \\
\hline Reithrodontomys sumichrasti & 12 & 5 & $42.0 \pm 2.0$ & $10.5 \pm 0.5$ & $0 \pm 0$ & $52.5 \pm 1.5$ & 2 & $1.0 \pm 1.0$ & $0 \quad 0 \pm 0$ \\
\hline Neotmodon alstoni & 3 & 1 & $21.0 \pm 0$ & $0 \pm 0$ & $0 \pm 0$ & $10.5 \pm 0.5$ & 0 & $0 \pm 0$ & $0 \pm 0$ \\
\hline \multicolumn{10}{|l|}{ Muridae } \\
\hline Mus musculus & 11 & 4 & $11.0 \pm 0$ & $10.5 \pm 0.5$ & $0 \pm 0$ & $63.0 \pm 0$ & 2 & $1.0 \pm 1.0$ & $0 \quad 0 \pm 0$ \\
\hline Abundance & 248 & 100 & $6030.0 \pm 0$ & $3517.5 \pm 3.5$ & $2525.0 \pm 2.0$ & $4623.0 \pm 2.0$ & 36 & $18.0 \pm 1.0$ & $2110.5 \pm 1.5$ \\
\hline Richness & 9 & & $87.5 \pm 05$ & $75.0 \pm 2.0$ & $54.5 \pm 0.5$ & $88.0 \pm 1.0$ & 7 & $6.0 \pm 1.0$ & $54.0 \pm 1.0$ \\
\hline ACE, Jackknife & & & $8,8.9$ & $10.04,9.75$ & 5.5 & $8.39,8.92$ & & 7,7 & $5.44,5.92$ \\
\hline Average estimators & & & 8.5 & 9.9 & 5 & 8.65 & & 7 & 5.68 \\
\hline$\%$ Completeness & & & 95 & 71 & 100 & 92 & & 100 & 88 \\
\hline
\end{tabular}

Taxonomic nomenclature was according to Ramírez-Pulido et al. 2014.

0.0385), the mean number of rodent individuals was significantly higher in oak-alder-forest during the dry season $(P=0.03)$.

Species responses. Nine rodent species were recorded in this study, but Microtus mexicanus and Neotomodon alstoni were excluded from the factorial analysis due to their low abundance $(n=3)$. There was no interaction effect between vegetation type and season for any species, although according to individual factor analyses only two species were sensitive to vegetation type, and none was affected by season. The abundance of Peromyscus melanotis differed among vegetation types $\left(F_{2,6}=12.80, P=0.003\right)$. Their capture was higher in pine forest than in grassland $(P=0.0005)$, and in oak-alder forest $(P=0.0167)$; but oak-alder forest registered more individuals than grassland $(P=0.0167 ;$ Table 1). Similarly, the abundance of Reithrodontomys fulvescens also differed between vegetation types $\left(F_{2,6}=5.80, P=0.0269\right)$; it was more abundant in oak-alder forest than in grassland $(P=0.0088)$ or in pine forest $(P=0.0190)$.

Changes in species dominance. P. melanotis and P. maniculatus were the most abundant species overall, both accounting for $53 \%$ of the total individuals captured (Table 1). Only N. alstoni was considered a rare species during the dry season ( 1 individual) and the wet season ( 2 individuals). Although the abundance of Mus musculus did not change between seasons or vegetation types, the dominance of this exotic species during the wet season is clearly higher than native species such as Reithrodontomys sumichrasti, R. megalotis, Microtus mexicanus and N. alstoni (Figure 3a). But in spite of these differences, overall species dominance did not differ between the dry and wet seasons $\left(F_{1,14}=0.51, P=0.48\right)$. 
a)

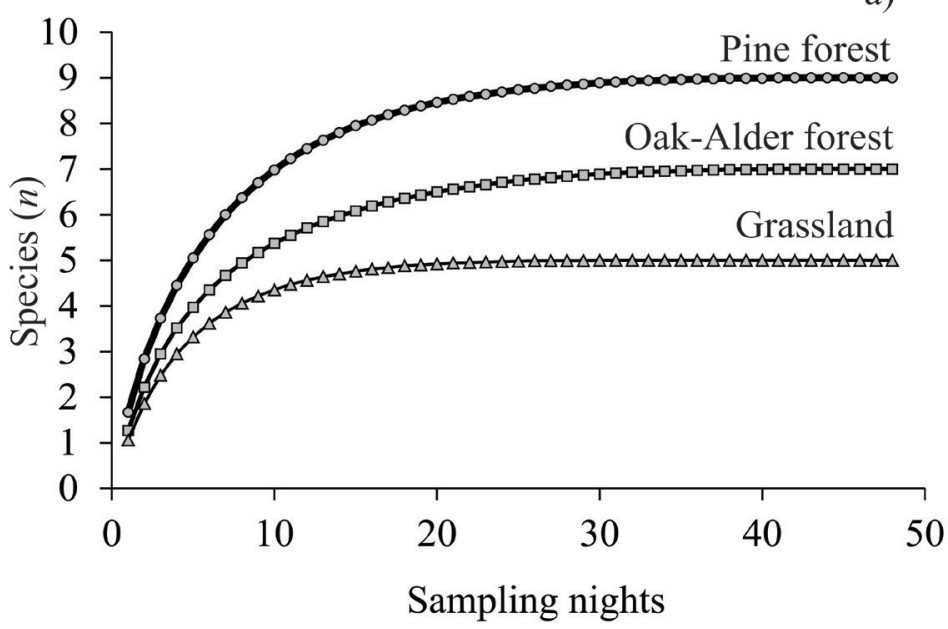

b)

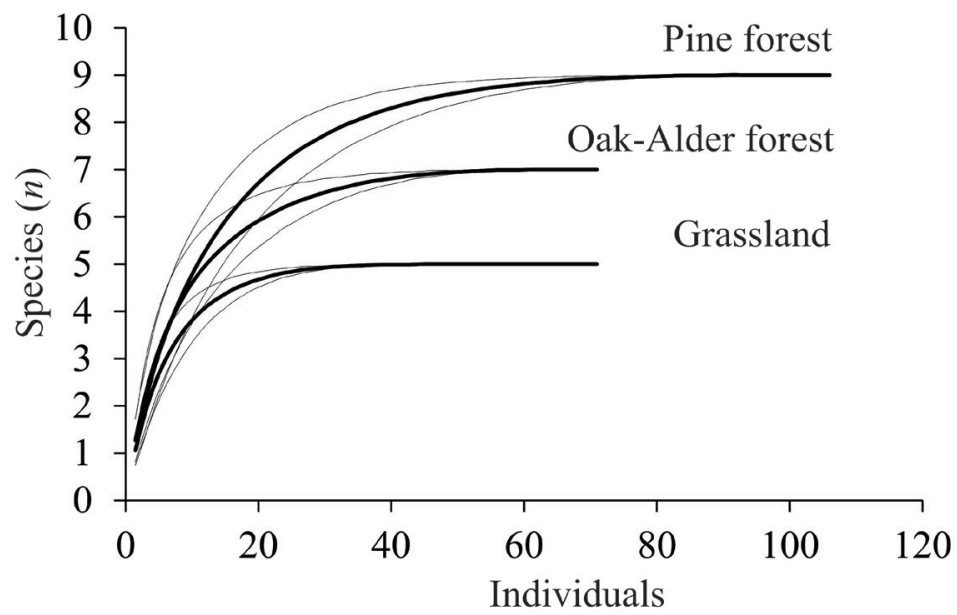

Figure 2. Accumulation curves (a) and rarefaction (b) of rodent species, recorded in the three vegetation types in a temperate forest in central Veracruz State, Mexico.

Rodent species dominance differed between vegetation types during the wet season $\left(F_{2,16}=\right.$ $12.78, P=0.0005)$. Rodent species in grassland were less diverse ( 5 species) than in pine forest ( 8 species $P=0.0005)$, or oak-alder forest (7 species $P=0.002$ ). The arrangement of rodent species assemblages varied according to vegetation types and season. During the wet season, the most dominant species was $P$. melanotis in pine forest, but in comparison oak-alder forest had more dominant species ( $P$. melanotis and $R$. fulvescens) than did pine forest and grassland (Figure 3a). Pine forest also registered the highest number of rare species (3 species), followed by oak-alder forest ( 2 species) and grassland (1 species).

During the dry season, rodent species dominance between vegetation types differed $\left(F_{2,16}=\right.$ $5.92, P=0.01)$, whereas dominance in the pine forest was higher than in the oak-alder forest ( $P$ $=0.009)$, $P$. melanotis and $P$. maniculatus versus $P$. melanotis respectively. Also in the dry season, pine forest and grassland were dominated by two species each ( $P$. melanotis, P. maniculatus and $P$. maniculatus, Reithrodontomys mexicanus) and oak-alder forest by one species (Figure 3b). However, oak-alder forest contained the highest number of rare species ( $R$. sumichrasti, R. megalotis and $M$. musculus) in comparison with the other two vegetation types (Figure 3b). 


\section{Discussion}

The number of nights on which trapping was done was 48 per vegetation type (total $=144$ ); however 33 nights were sufficient to achieve the asymptote in the species accumulation curve. We recorded nine rodent species, which was consistent with the pattern of richness (Mean 9 \pm 1.41 SD) reported for other pine forests in Mexico (Coronel and Arellano 2004; Aragon et al. 2009; Cuautle-Garcia 2007; Cruz et al. 2010). However, the completeness of our inventory was
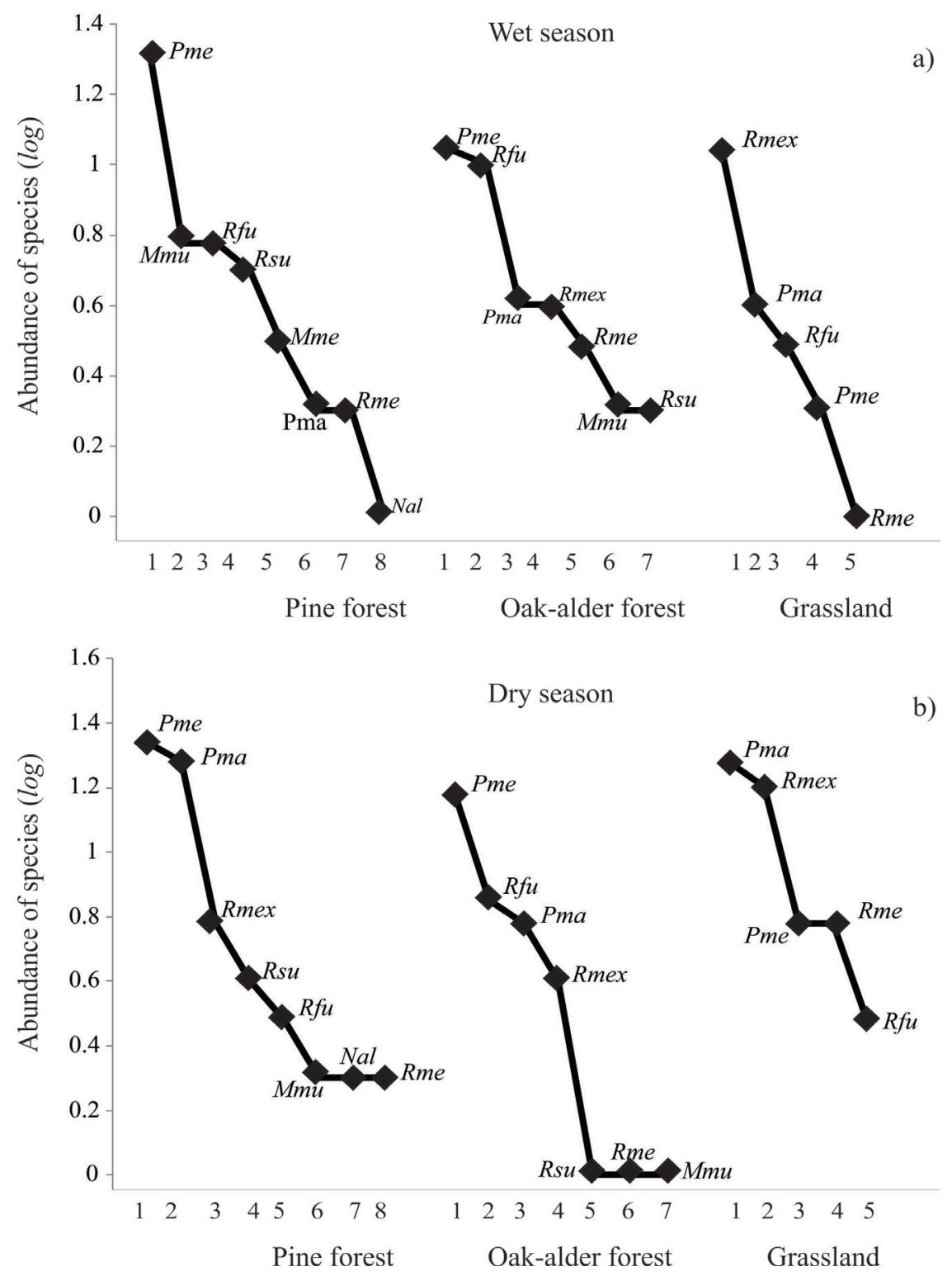

Figure 3. Rank abundance curves for rodent species recorded in three vegetation types for the wet season (a), and the dry season (b), in a temperate forest in central Veracruz State, Mexico. The code for each species corresponds to an abbreviation of its scientific name (Mus musculus = Mmus). On the $Y$ axis species abundance is transformed to log 10, and on the $\mathrm{X}$ axis the number of species is recorded for each type of plant community.

only satisfactory in the dry season for the pine forest and grassland, and for the pine forest and oak-alder forest in the wet season that is exceeding $90 \%$ completeness (Table 1). This may be because in these vegetation types the abundance of individuals registered for each species was more homogeneous (Table 1), nonparametric estimators such as ACE and Jackknife being sensitive to abundance parameters (Magurran 2004), assuming that while there are more rare 
species in a given vegetation type, the higher the probability will be for new species to appear in the inventory and the completeness level will not be expected to exceed $90 \%$ (Petersen and Meier 2003). Similarly, seasonality is a factor that may affect the reliability of species inventories influenced by the movements of individuals between plant communities in relation to resource availability, a particular attribute of rodent assemblages (Krebs et al. 2010; Rautenbach et al. 2014; Ofori et al. 2015).

Peromyscus melanotis and $P$. maniculatus were the most abundant species, as has also been reported in different Mexican pine-oak forests (Hall 1981; Orduña-Trejo et al. 1999; Cuautle-García 2007; Ruiz-Soberanes and Gómez-Álvarez 2010) and temperate forests of North America (CeballosGonzález and Galindo-Leal 1984; Musser and Carleton 2005). Both species are also opportunistic species and they are also widely distributed in coastal, alpine, forests, grasslands, shrub lands, deserts and tropical areas (Ceballos-González and Galindo-Leal 1984; Martínez-Coronel et al. 1991).

Species richness was not affected by the interaction (vegetation type* season), or individually by these factors. This result likely reflected the fact that species collected during this study are common inhabitants of the vegetation types studied with reproduction occurring all year long (Ceballos and Oliva 2005). In contrast, rodent abundance was clearly affected by the interaction between vegetation type and season. Commonly, abundance in rodent communities changes seasonally because of annual climate variation, which determines the ecosystem productivity and the phenology of seed production (Cortes-Flores et al. 2011; Jackson et al. 2009; Nicolas and Colyn 2003). We found that among vegetation types the abundance of mice was higher in oak-alder forest during the dry season (Table 1). This coincides with the period of fruit production and seed dispersal of the oak-alder forest from March to May. This is because higher air temperature increases the opening of cones of Alnus and favors more acorns and seed presence on the ground (Niembro 1986; Cortes-Flores et al. 2011). The availability of these resources is consistent with the greater abundance of rodents at sites with greater vegetation cover and food availability (Tapia-Ramirez et al. 2012), as has been reported for rodents from the Peromyscus genus whose variation in dispersal depends on the abundance of food resources (Wang et al. 2009) and a low risk of predation common in areas with dense vegetation cover (Whelan et al. 1991; LoGiudice and Ostfeld 2002).

The abundance of $P$. melanotis was highest in the pine forest and oak-alder forest. These results are similar to those documented by Ruiz-Soberanes and Gómez-Álvarez (2010) from the temperate forest of La Malinche National Park, Tlaxcala, México, where P. melanotis was also abundant in the pine forest and oak-alder forest. Rodents of $P$. genus have high reproductive capacity throughout the year in this region, and particularly $P$. melanotis does not have conservation problems (Ceballos and Oliva 2005). Rodents commonly favor areas with plant cover where the availability of resources is greater under the canopy of parent trees because seed density is high (Vander Wall 2002; Hulme and Kollmann 2005). The abundance of Reithrodontomys fulvescens also was higher in oak-alder forest than in grassland and in pine forest, a pattern similar to that reported by RuizSoberanes and Gómez-Álvarez (2010). R. fulvescens prefers oak-alder forest possibly because of increased availability of food resources such as invertebrates, acorns, and alder and pine seeds which are dispersed by wind (Ceballos and Oliva 2005).

Dominance of species did not differ among seasons, probably because all rodent species are similarly abundant throughout the year (Ceballos and Oliva 2005). Nevertheless, rodent species dominance differed between vegetation types during the wet season. P. melanotis was the most dominant species in pine forest where we also recorded the highest number of rare species such as M. mexicanus, M. musculus and $N$. alstoni. In the wet season, vegetation cover increases and favors different habitat conditions and availability of food resources that can support a greater 
number of species and individuals with different dietary requirements (Milstead et al. 2007). In our case, $P$. melanotis consume seeds and seedlings that are common on the pine forest floor. This suggests that rodents forage in sites with greater food availability, which could explain the greater abundance of certain species during the wet period. Grassland was less favored than pine forest and oak-alder forest, due to its structural simplicity and the possible existence of a higher risk of predation by carnivores (Morris and Davidson 2000; LoGiudice and Ostfeld 2002).

During the dry season, the pine forest contained more dominant rodent species ( $P$. melanotis and $P$. maniculatus) than the oak-alder forest ( $P$. melanotis), and here we also recorded a higher number of rare species such as $R$. sumichrasti, R. megalotis and $M$. musculus. This last species is able to displace native species with more specific habitat requirements due to its high reproductive capacity (Álvarez-Romero 2008). In warmer months such as February-June air temperature favors the opening of pine cones and seed dispersal (Perry 1991), and this generates higher food availability that favors the abundance of rodents (Wang et al. 2009). Although vegetation structure was not characterized in this study, we noticed that the confidence intervals of the rarefaction curves do not overlap (Figure $2 b$ ). Considering this as a robust statistical comparison (see MacGregor-Fors and Payton, 2013), we can confidently conclude that pine and oak alder patches had significantly more species ( 8 and 7 species respectively) than grassland with 5 species. This indicates that areas structurally more complex in vegetation favor a higher rodent species richness because they provide more resources such as food and shelter, features consistently associated with particular seasons. However, rodents such as $P$. maniculatus and $R$. mexicanus can also remove seeds from open areas that provide food resources throughout the year due to the presence of perennial species such as Muhlenbergia macroura. Therefore the presence of isolated trees or shrubs in grasslands may offer potential shelter and food resources for these habitat generalist species. These findings suggest that integrated conservation of pine forest, oakalder forest, and subalpine grassland is essential for maintenance of rodent populations and their ecological roles in temperate forest dynamics.

\section{Conclusions}

Our results demonstrate that vegetation type is an important variable related to rodent diversity. Pine and oak-alder forests supported the highest number of rodent species, namely eight and seven respectively. Peromyscus melanotis and Reithrodontomys fulvescens in particular were favored in areas with complex plant cover because forest habitats have a higher availability of food resources and shelter. Moreover, three rare species, R. sumichrasti, R. megalotis and M. musculus, were recorded in the oak-alder forests.

Seasonality is also a major factor that determines how individuals use vegetation types because it influences the dynamics of their food resources and reproductive periods. Rodent abundance was higher during dry seasons and particularly in oak-alder forest where there are possibly more varied resources such as alder seeds, acorns and pine seeds dispersed in the wind. During this season, species such as $P$. melanotis and $P$. maniculatus were more dominant in the pine forest than oak-alder forest where only $P$. melanotis was a dominant species. This is because in these sites the heterogeneity and productivity are higher due to the high level of fruit and seed production and dispersal that is common from March to May. In wet seasons P. melanotis was the most dominant species in pine forest where a high number of rare species was also recorded, namely M. mexicanus, $M$. musculus and N. alstoni. These findings emphasize the important role of seasonality in influencing the rodent component of the communities we investigated.

Although the non-native species Mus musculus remains rare in these habitats, its distribution, abundance, and interspecific interactions should be studied more because of its potential to 
displace native rodents such as Reithrodontomys sumichrasti, R. megalotis, M. mexicanus and N. alstoni. This last is an endemic species restricted to the Trans-Mexican Volcanic Belt.

An important conclusion from this investigation of multiple species in multiple habitats is that these diverse communities are complexly connected with numerous interactions among them. Conservation planning needs to take this connectivity into account with a strategy that aims to preserve a mosaic of vegetation types, and thereby preserve all the parts and all the ecosystem functions for maximum effectiveness.

\section{Acknowledgments}

The National Council for Science and Technology awarded a PhD scholarship (175058) to the first author. Thanks to J. Galindo (INBIOTECA-UV) for logistical support and A. Gonzalez (IIB-UV) for help in identifying specimens. We thank two anonymous referees for valuable suggestions and comments. The Veracruz State Government allowed us the use of the facilities of the San Juan del Monte Nature Reserve. Help from the park rangers M. Becerra and A. Becerra as well as the biologist R. Hernandez was indispensable during fieldwork.

\section{Cited literature}

Álvarez-Romero, J. G., R. A. Medellín, A. Oliveras de Ita, H. Gómez de Silva, and O. Sánchez. 2008. Animales exóticos en México: una amenaza para la biodiversidad. Comisión Nacional para el Conocimiento y Uso de la Biodiversidad. Instituto de Ecología. Universidad Nacional Autónoma de México, Secretaría del Medio Ambiente y Recursos Naturales. Ciudad de México, México.

Aragón, E. E., A. Garza, and F. A. Cervantes. 2009. Estructura y organización de los ensambles de roedores de un bosque de la Sierra Madre Occidental, Durango, México. Revista Chilena de Historia Natural 82:523-542.

Avenant, N. 2011. The potential utility of rodents and other small mammals of indicators of ecosystem integrity of South African grasslands. South African Journal of Wildlife Research 38:626-639.

Castillo-Guevara, C., C. Lara, and G. Pérez. 2012. Mycophagy by rodents in a temperate forest of Central Mexico. Revista Mexicana de Biodiversidad 83:772-777.

Ceballos, G., And G. Oliva (Eds.). 2005. Los mamíferos silvestres de México. Comisión Nacional para el Conocimiento y Uso de la Biodiversidad. Fondo de Cultura Económica, Colección: Sección de Obras de Ciencia y Tecnología. Ciudad de México, México.

Ceballos-González, G., And C. Galindo-Leal. 1984. Mamíferos Silvestres de la Cuenca de México. Editorial Limusa. Ciudad de México, México.

Cervantes, F. A., and C. Ballesteros-Barrera (Eds.). 2012. Estudios sobre la biología de roedores silvestres mexicanos. Universidad Nacional Autónoma de México, Instituto de Biología. Universidad Autónoma Metropolitana. Ciudad de México, México.

Challenger, A. 1998. Utilización y conservación de los ecosistemas terrestres de México: Pasado, presente y futuro. Comisión Nacional para el Conocimiento y Uso de la Biodiversidad. Instituto de Biología, Sierra Madre. Ciudad de México, México.

Colwell, R. K. 2013. EstimateS: Statistical estimation of species richness and shared species from samples (Software and User's guide). Version 9.1.0. Connecticut, EE. UU.

CONAFOR (Comisión Nacional Forestal). 2010. Programa Nacional de Protección contra Incendios Forestales. Secretaría del Medio Ambiente y Recursos Naturales. Zapopan, México.

Cortes-Flores, J., G. Cornejo-Tenorio, and G. Ibarra-Manríquez. 2011. Fenología reproductiva de las especies arbóreas de un bosque neotropical. Interciencia 36:608-613.

Coronel-Arellano, H. 2004. Inventario de la Mastofauna terrestre: el caso del rancho Santa Elena, Huasca de Ocampo, Hidalgo. Tesis de Licenciatura. Universidad Autónoma del Estado de Hidalgo. 
Pachuca de Soto, México.

Cuautle-García, L. M. 2007. Diversidad de roedores en la reserva de la biósfera la Michilia en relación con la heterogeneidad ambiental a nivel macrohábitat y microhábitat. Tesis de Maestría. Instituto de Ecología, A. C. Xalapa, México.

Cruz, L. E., C. Lorenzo, O. G. Retana, and E. C. Sántiz. 2010. Interspecific variability in the abundance of small rodents on the highlands of Chiapas, Mexico. Therya 1:129-136.

Flores-Peredo, R., L. R. Sánchez-Velásquez, J. Galindo-González, and J. Morales-Mávil. 2011. Post-dispersed pine seed removal and its effect on seedling establishment in a Mexican Temperate Forest. Plant Ecology 212:1037-1046.

Gee, J. H. R., AND P. S. Giller. 1987. Organization of communities, Past and Present. Blackwell Scientific Publications. Oxford, United Kingdom.

Gomez-Mendoza, L, And Arriaga-Cabrera, L. 2007. Effects of climate change in Pinus and Quercus distribution in Mexico. Conservation Biology 21:1545-1555.

González-Christen, A., N. V. Rodríguez-Santiago, and G. Marín-Gómez. 2012. Composición del ensamble de pequeños mamíferos del borde de un bosque mesófilo de montaña en Veracruz, México. Pp. 85-95 en Estudios sobre la biología de roedores silvestres mexicanos (Cervantes, F. A., and C. Ballesteros-Barrera, eds.). Universidad Nacional Autónoma de México, Instituto de Biología. Ciudad de México, México.

González-Medrano, F. 2004. Las comunidades vegetales de México: Propuesta para la unificación de la clasificación y nomenclatura de la vegetación de México. Secretaría de Medio Ambiente y Recursos Naturales. Instituto Nacional de Ecología. Ciudad de México, México.

Gotelli, N. J., And R. K. Colwell. 2011. Estimates species richness. Pp. 39-54 in Frontiers in measuring biodiversity (Magurran, A. E., and B. J. McGill, eds.). Oxford University Press. New York, EE. UU.

HALL, E. R. 1981. The mammals of North America. 2th edition. John Wiley and Sons. New York, EE. UU.

Hernández-Flores, S. D., and A. E. Rojas-Martínez. 2010. Lista actualizada y estado de conservación de los mamíferos del Parque Nacional el Chico, Hidalgo, México. Acta Zoológica Mexicana 26:563-583.

Horvath, G., D. MolnáR, AND G. CsonKa. 2007. Population dynamics and spatial patterns of small mammals in protected forest and reforested areas. Natura Somogyiensis 7:191-207.

Hulme, P. E., and J. Kollmann. 2005. Seed Predator Guilds, Spatial Variation in Post-dispersal Seed Predation and Potential Effects on Plant Demography: a Temperate Perspective. Pp. 9-30 in Seed Fate: Predation, Dispersal and Seedling Establishment (Forget, P. M., J. E. Lambert, P. E. Hulme, and S. B. Vander-Walls, eds.). CABI. Wallingford, England.

Jackson, S. T., J. L. Betancourt, R. K. Booth, and S. T. Gray. 2009. Ecology and the ratchet of events: climate variability, niche dimensions, and species distributions. Proceedings of the National Academy of Sciences 106:19685-19692.

Johnson, S. D., P.M. Burgoyne, L. D. Harder, AND S. Dötterl. 2011. Mammal pollinators lured by the scent of a parasitic plant. Proceedings of the Royal Society B 278:2303-2310.

Jorgensen, E. E. 2004. Small mammal use of microhabitat reviewed. Journal of Mammalogy 85:531-539.

Jorgensen, E. E., and S. Demarais. 1999. Spatial scale dependence of rodent habitat use. Journal of Mammalogy 89:421-429.

Krebs, C. J., K. Cowcill, R. Boonstra, and A. J. Kenney. 2010. Do changes in berry crops drive population fluctuations in small rodents in the southwestern Yukon? Journal of Mammalogy 91:500-509.

Lindenmayer, D. B., AND J. Fisher. 2006. Habitat fragmentation and landscape change. An ecological and conservation synthesis. CSIRO Publishing. Melbourne, Australia.

LoGiudice, K., AND R. S. Ostreld. 2002. Interactions between mammals and trees: predation on mammaldispersed seeds and the effect of ambient food. Oecologia 130:420-425.

MacGregor-Fors, I., AND M. E. Payton. 2013. Contrasting diversity values: Statistical inferences based on overlapping confidence intervals. PloS One 8:e56794. 
MagurRan, A. E., 2004. Measuring biological diversity. Blackwell Publishing. Oxford, EE. UU.

Malcom, J. R., AND J. C. Ray. 2000. The influence of timber extraction routes on central African small mammal communities, forest structure and tree diversity. Conservation Biology 14:1623-1638.

Manning, J. A., And W. D. Edge. 2008. Small mammal responses to fine woody debris and forest fuel reduction in southwest Oregon. Journal of Wildlife Management 72:625-632.

Martínez-Coronel, M., J. Ramírez-Pulido, and T. Álvarez. 1991. Variación intrapoblacional de Peromyscus melanotis (Rodentia: Muridae) en el Eje Volcánico Transverso, México. Acta Zoológica Mexicana (n. s.) 47:1-51.

Milstead, W. B., P. L. Meserve, A. Campanella, M. A. Previtali, D. A. Kelt, and J. R. Gutiérrez. 2007. Spatial ecology of small mammals in north-central Chile: role of precipitation and refuges. Journal of Mammalogy 88:1532-1538.

Morales-García, J. J. 2007. Ensamblaje de mamíferos terrestres en un bosque templado en áreas bajo diferente manejo forestal en Huasca de Ocampo, Hidalgo, México. Tesis de Licenciatura. Universidad Autónoma del Estado de Hidalgo. Pachuca de Soto, México.

Moreno, C. E., And G. Halffter. 2000. Assesing the completeness of bat biodiversity inventories using species accumulation curves. Journal of Applied Ecology 37:149-158.

MorRIs, D. W., AND D. L. Davidson. 2000. Optimally foraging mice match patch use with habitat differences in fitness. Ecology 81:2061-2066.

Musser, G. G., And M. D. Carleton. 2005. Superfamily Muroidea. Pp. 894-1531 in Mammal Species of the World a Taxonomic and Geographic Reference (Wilson, D. E., and D. M. Reeder, eds.). Johns Hopkins University Press. Baltimore, EE. UU.

Nicolas, V., AND M. Colyn. 2003. Seasonal variations in population and community structure of small rodents in a tropical forest of Gabon. Canadian Journal of Zoology 81:1034-1046.

Niembro, R. A. 1986. Mecanismos de reproducción sexual de pinos. Editorial Limusa. Ciudad de México, México.

Ofori, B. Y., D. K. Attuquayefio, E. H. Owusu, R. K. Y. Musah, J. K. Quartey, and Y. Ntiamoa-Baidu. 2015. Seasonal changes in small mammal assemblage in Kogyae Strict Nature Reserve, Ghana. International Journal of Biodiversity and Conservation 7:238-244.

Orduña-Trejo, C., A. Castro-Campillo, and J. Ramírez-Pulido. 1999. Mammals from the Tarascan Plateau, Michoacán México. Revista Mexicana de Mastozoología 4:53-68.

Pardini, R., S. Marques de Sousa, R. Braga-Neto, and J. P. Metzger. 2005. The role of forest structure, fragment size and corridors in maintaining small mammal abundance and diversity in an Atlantic forest landscape. Biological Conservation 124:253-266.

Pearson, D. E., And L. F. Ruggiero. 2003. Transect versus Grid Trapping Arrangements for Sampling SmallMammal Communities. Wildlife Society Bulletin 31:454-459.

Petersen, F. T., And R. Meier. 2003. Testing species-richness estimation methods on single-sample collection data using the Danish Diptera. Biodiversity and Conservation 12:667-686.

Perry, J. P. 1991. The Pines of Mexico and Central America. Timber Press. Portland, EE. UU.

Ramirez-Pulido, J., N. González-Ruíz, A. L. Gardner, and J. Arroyo-Cabrales. 2014. List of Recent Land Mammals of Mexico. Special publications, Museum of Texas, Tech University 63:1-69.

Rautenbach, A., T. Dickerson, and M. C. Schoeman. 2014. Diversity of rodent and shrew assemblages in different vegetation types of the savannah biome in South Africa: no evidence for nested subsets or competition. African Journal of Ecology 52:30-40.

Rzedowskı, J. 2006. Vegetación de México. First edition digital. Comisión Nacional para el Conocimiento y Uso de la Biodiversidad. Ciudad de México, México.

Roвert, S. 2016. Sikes and the Animal Care and Use Committee of the American Society of Mammalogists. Journal of Mammalogy 97:663-668.

Ruiz-Soberanes, J. A., And G. Gómez-Álvarez. 2010. Estudio Mastofaunístico del Parque Nacional la 
Malinche, Tlaxcala México. Therya 1:97-110.

Sánchez-Colón, S., A. Flores Martínez, I. A. Cruz-Leyva, and A. Velázquez. 2009. Estado y transformación de los ecosistemas terrestres por causas humanas. Pp. 75-129 in Capital natural de México, vol. II (Dirzo, R., R. González., and I. J. March eds.). Comisión Nacional Para el Conocimiento y Uso de la Biodiversidad. Ciudad de México, México.

Sánchez, O., E. Vega, E. Peters, and O. Monroy-Vilchis. 2003. Conservación de ecosistemas templados de montaña en México. Instituto Nacional de Ecología. Ciudad de México, México.

Sánchez-Cordero, V., and R. Martínez-Gallardo. 1998. Postdispersal fruit and seed removal by forestdwelling rodents in a lowland rainforest in Mexico. Journal of Tropical Ecology 14:139-151.

Siry, J. P., P. Bettinger, K. Merry, D. L. Grebner, K. Boston, and C. H. Cieszewski. 2015. Forest Plans of North America. Elseiver Academic Press. Washington, EE. UU.

Tapia-Ramírez, G., C. López-González, A. González-Romero, and S. F. Hernández-Betancourt. 2012. Diversidad de roedores y su relación con la heterogeneidad ambiental en la cuenca del río Nazas, Durango, México. Pp. 59-70 in Estudios sobre la biología de roedores silvestres mexicanos (Cervantes, F. A., and C. Ballesteros-Barrera, eds.). Universidad Nacional Autónoma de México, Instituto de Biología. Ciudad de México, México.

Vander W All, S. B. 2002. Masting in animal-dispersed pines facilities seed dispersal. Ecology 83:35083516.

Vázquez, L. B., R. A. Medeluin, And G. N. Cameron. 2000. Population and community ecology of small rodents in Montane Forest of Western Mexico. Journal of Mammalogy 81:77-85.

Wang, G. M., J. O. Wolff, S. H. Vessey, N. A. Slade, J. W. Whitam, J. F. Merritt, M. L. Hunter, Jro, and S. P. ElıAs. 2009. Comparative population dynamics of Peromyscus leucopus in North America: influences of climate, food and density dependence. Population Ecology 51:133-142.

Whelan, C. J., M. F. Willson, C. A. Tuma, And I. Souzapinto. 1991. Spatial and temporal patterns of postdispersal seed predation. Canadian Journal of Botany 69:428-436.

Wilson, D. E., And D. A. Reeder. 2005. Mammal species of the world: A taxonomic and geographic reference. The Johns Hopkins University Press. Baltimore, EE. UU.

Zar, J. H. 2010. Biostatistical Analysis. $5^{\text {th }}$ edition. Prentice Hall, Inc. New Jersey, EE. UU.

Submitted: March 28, 2016

Reviewed: June 4, 2016

Accepted: August 2, 2016

Associated editor: William Lidicker 
RODENT ASSEMBLAGE

370 THERYA Vol.7 (3): 357-369 